\title{
Characterization of PhotoprotectiveCompounds in Marine Zooplankton of the Southwest Coast of India: An Ecological Perspective
}

\author{
Nallathambi T ${ }^{1, *}$, Robin R. S ${ }^{2}$, K.Vishnu Vardhan², Pradipta R. Muduli ${ }^{2}$ \\ ${ }^{1}$ Vessel Management Cell, National Institute of Ocean Technology, Chennai, 600100, India \\ ${ }^{2}$ ICMAM Project Directorate, Ministry of Earth Sciences, NIOT Campus, Pallikaranai, Chennai, 600100, India
}

\begin{abstract}
Inthe marine environment, organisms are under threat due to several environmental fluctuations such as ultraviolet (UV) radiation, coastal pollution etc. However, it is encouraging to note that the marine organisms try to protect themselves from UV-radiation by synthesizing photprotective compounds. Since phytoplankton can synthesize the UV-protecective compounds and are grazed by zooplankton, we investigated the presence of photoprotective compounds in zooplankton. In this context, a study has been conducted for the first time in the shelf waters of the southwest coast of Arabian Sea, India for the characterization of photoprotective compounds in the zooplankton community. The study revealed the presence of photoprotective compounds, such asporphyra and palythine in the zooplankton community of all the stations, in addition to mycosporine glycine, in the polluted waters of the stations, Veli, Neendakari and Cochin.
\end{abstract}

Keywords Arabian Sea, Mycosporine like amino acids, zooplankton, UV-protective compounds, antioxidant metabolites

\section{Introduction}

Impact of UV- radiation on aquatic food webs has been stimulated by realizing the increasing levels of UV- radiation reaching earth's surface[1]. Despite the low intensity at the ground level, it causes biological damage because of the high-energy content of photon, and the DNA damage via the formation of cyclobutane and pyrimidine dimers[2-6]. One possible strategy by the organisms to protect themselves against UV-radiation is by the synthesis of UV-absorbing compounds that act as natural sunscreens. One such compound, mycosporine, identified in fungi was found to have a role in UV-induced sporulation[7-10]. Mycosporine like amino acids (MAAs) are found in marine organisms, from bacteria to fish $[11,12]$ and in terrestrial microorganisms like fungi[13]. High concentrations of MAAs are found in epilithiccyanobacterial or algal mats[14, 15]. Accumulation of MAAs has also been reported for the population of the copepod, Boeckellatiticacae from the tropical high altitude Lake Titicaca[16]. Concentration of MAAs in the population of Cyclops abyssorum and C.abyssorumtatricus from the lakes in the Alps has been found to increase exponentially with lake elevation and underwater UV transparency.

* Corresponding author:

drthambi@gmail.com (Nallathambi T)

Published online at http://journal.sapub.org/ms

Copyright (C) 2012 Scientific \& Academic Publishing. All Rights Reserved
Copepods of alpine lakes also accumulate high amounts of carotenoids that give them the intense red appearance and provide with added protection[17-19]. Concentration of these compounds in the calanoid copepods was found to be increased with lake elevation and shallowness of the system, thus establishing a direct correlation between the concentration and the UV-intensity[20]. Suchenvironmental factors besides UV exposure are also important in regulating the synthesis of MAAs[21].

During the past two decades, a substantial loss in the stratospheric ozone layer has been noticed that has aroused interest in studying the effects of increased ultraviolet radiation (UVR), particularly UV-B radiation $(280-315 \mathrm{~nm})$, on the earth's surface. Solar UV-B radiation is detrimental to most sun-exposed organisms, including humans[22]. An increase in UV-B radiation has led to search for the natural photoprotective compounds from various organisms such as microorganisms, plants and animals of marine as well as freshwater ecosystems. A number of photoprotective compounds, such as melanins, MAAs, scytonemin, parietin, usnic acid, carotenoids, phycobiliproteins, phenylpropanoids and flavonoids and several other UV-absorbing substances of unknown chemical structure have been identified from different organisms[23-25].

There have been a number of reviews about diverse classes of compounds from natural sources, including marine habitats, but the occurrence of photoprotectants from marine sources has only partially been elucidated. Ultraviolet ra- 
diation (UVR) is one of the most harmful exogenous agents and may affect a number of biological functions in all sun exposed living organisms. Solar radiation exposes the organisms to harmful doses of UV-B and UV-A (315-400 nm) radiation in their natural habitats. In response to intense solar radiation, organisms have evolved positive mechanisms such as avoidance, repair and protection by synthesizing or accumulating a series of photoprotective compounds, such as MAAs, scytonemin, carotenoids and certain other compounds to counteract the toxicity of UV (particularly UV-B) radiation[26-29]. Furthermore, MAAs is the most common compounds with a potential role as UV sunscreens in marine organisms. It has been found that MAAs provides protection from UVR not only for their producers, but also to primary and secondary consumers through the food chain[30].

Production of MAAs from marine zooplankton requires holistic understanding the transfer of MAAs from primary to higher trophic levels through the marine food chain. Findings during this investigation are considered important since much of our knowledge on MAAs is from the fresh water habitat and temperate waters. Studies on the MAAs production from the shelf waters of tropical environments are lacking. Hence, an attempt was made for the first time in this regard along the shelf waters of southwest coast, India. This study investigated the relationship among zooplankton, chlorophylla, productivity and photoprotective compounds characterization in zooplankton community with the existing environmental conditions.

\section{Materials and methods}

Study was carried out at thirteen stations along $(\sim 1400 \mathrm{~km}$ stretch between $8^{\circ} \mathrm{N}$ and $14^{\circ} \mathrm{N}$ lat) the shelf waters of the southwest coast of Arabian Sea, India, in which eight stations were selected from off Kerala coast and five from off

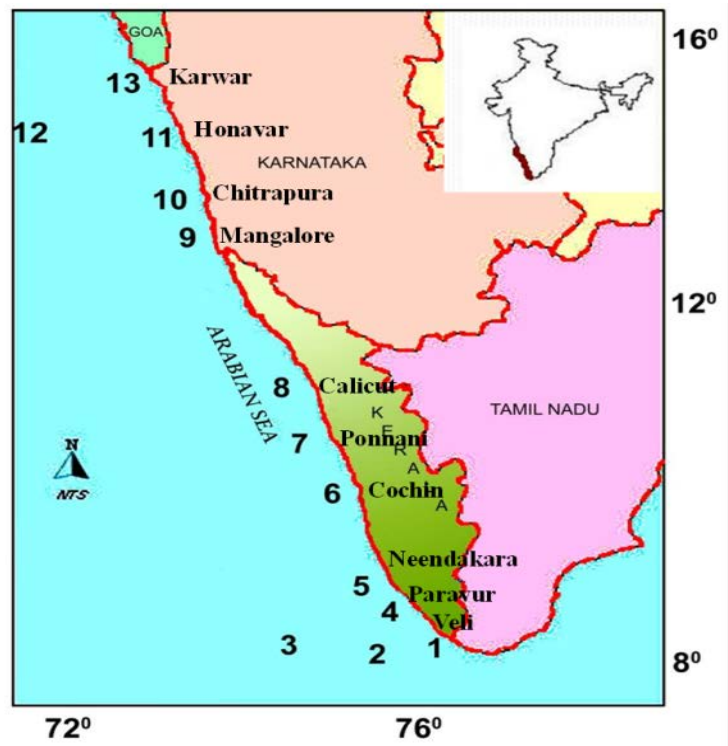

1. Veli-A, 2.Veli-B, 3.Veli-C, 4.TTP*, 5.Neendakara, 6.Cochin, 7.Kodungallur, 8.Calicut, 9.Mangalore, 10.Chitrapura, 11. Honavar-A,12. Honavar-B, 13.Karwar * Travancore Titanium Products.

Figure 1. Study area map with sampling locations
Karnataka Coast (Figure 1) Samples were collected during the CRV SagarPurvi cruise from May to June 2005. The southwest coast of India is a monsoon dominated coast. Upwelling occurs along the coast during the southwest monsoon (June to September) season between $14{ }^{\circ} \mathrm{N}$ and 7 ${ }^{\circ} \mathrm{N}[31,32]$.

Sub surface water samples representing the photic layer, were collected using a 5L Niskin sampler for physicochemical parameters, such as $\mathrm{pH}$, salinity, temperature, dissolved oxygen (DO), chlorophyll $a$ and primary production. Temperature was recorded using a thermometer $\left(1-51^{\circ} \mathrm{C}\right.$ range within $\pm 0.1^{\circ} \mathrm{C}$; Brannan, UK). $\mathrm{pH}$ was measured using a portable $\mathrm{pH}$ meter, WTW MultiLine P4, having a range of 0 to 14 , resolution of 0.01 and accuracy \pm 0.05 . Salinity was determined using a Digi auto salinometer (Model TSK, accuracy \pm 0.1 ). DO was measured using Winkler's titration method of Grasshoff et al.[33], the analytical precision, expressed as standard deviation $( \pm 0.07 \%)$. llitre water sample was filtered through glass fiber filter (GF/F; Whatman) for chlorophyll $a$ analysis.Chlorophylla retained on the filter was extracted with $90 \%$ acetone at $4{ }^{\circ} \mathrm{C}$ in dark for $24 \mathrm{~h}$, and measured spectrophotometrically[34]. The analytical precision for chlorophylla analysis was $\pm 4 \%$.

Primary production was estimated by in-situ method using the ${ }^{14} \mathrm{C}$-technique[35]. Water samples were collected before the sunrise, immediately passed through $200 \mu$ sieve to remove large sized zooplankton and transferred to $300 \mathrm{ml}$ capacity Nalgene bottles ( 3 light bottles and 1 dark bottle). After the inoculation of $1 \mathrm{ml}$ of $\mathrm{NaH}^{14} \mathrm{CO}_{3}$ (activity $5 \mu \mathrm{Ci}$ ) solution, the light and dark bottles were deployed in a mooring system at respective depth for $12 \mathrm{~h}$ for incubation. The experiments were terminated by filtering the samples on to $47 \mathrm{~mm}$ Whatman GF/F filters and the filters were used for subsequent analysis in a liquid scintillation counter[35] after treatment with $\mathrm{HCl}$ fumes to remove inorganic carbon.

Zooplankton samples were collected with a net (mesh size $100 \mu \mathrm{m}$ ) having a diameter of $0.6 \mathrm{~m}$, towed horizontally just below the surface for a duration of 10 min (speed 1 knot). The net was fitted with a calibrated flow meter (General Oceanics, Model-2030) to quantify the volume of water filtered. Collected zooplankton samples were placed in two sets of prewashed (Milli-Q) polycarbonate bottles. One was stored at $-4^{\circ} \mathrm{C}$ for the characterization of MAAs and the other was fixed with $4 \%$ formalin. Qualitative and quantitative analysis of zooplankton were performed following stringent methods[36-38]. Zooplankton samples werefiltered through a Whatman GF/F filter and frozen at $-80^{\circ} \mathrm{C}$ for subsequent extraction of MAAs. Extraction was done in tightly capped vials containing $0.75-1.5 \mathrm{ml}$ of $25 \%$ aqueous methanol $\left(24-48 \mathrm{~h}\right.$ at $25^{\circ} \mathrm{C}$, sonicated before analysis). The extracts were subsequently dried under vacuum in $2 \mathrm{ml} \mathrm{Ep}$ pendrof micro centrifugation tubes, using a SpeedVac concentrator at $4^{0} \mathrm{C}$ and stored at $-80^{\circ} \mathrm{C}$ for further characterization. The concentrated extracts wereresuspended in 0.5 to $2 \mathrm{ml}$ of $25 \%$ aqueous methanol ( $\mathrm{v} / \mathrm{v})$ and they were analyzed chromatographically by isocratic high-performance liquid chromatography (HPLC)[39]. We used a Shimadzu 
LC-10AD/SCL-10A chromatograph with SPD-10AV stopflow scanning spectrophotometric detector (recording 313, $340 \mathrm{~nm}$ ) and a Brownlee C18 column (250 x $4.6 \mathrm{~mm})$. For routine analyses, the mobile phase was $25 \%$ (vol:vol) aqueous methanol with $0.1 \%$ acetic acid, at $0.8 \mathrm{ml} \mathrm{min}^{-1}$. The MAAs were identified by chromatography by comparing the absorption spectra and retention times with standards provided by Dr.Oliver Nixdorf, University of Bremen, Germany.

\section{Results and Discussion}

Variations in hydrographic characteristics along southwest waters were presented in (Figure 2 a-d).South west coast has a warm humid climate with $\sim 32^{\circ} \mathrm{C}$ air temperature. Water column remained relatively cool (avg. $28.16 \pm 0.73^{\circ} \mathrm{C}$ ) except station Veli. Salinity is one of the prime factors, which influences the abundance and distribution of the fauna and flora in the coastal waters. Salinity (avg. $28.94 \pm 5.59$ ) showed a wide fluctuation at stations proximal to estuaries. Low $\mathrm{pH}$ recorded at southern stations (Veli, Paravur, Neendakara) showed a great fluctuation among the stations. At Veli pH was 3.32, indicating the extremity of acidic factory effluents discharged from Travancore Titanium Product factory (TTP). This is in agreement with the observationsofearlier studies[40]. Relatively high DO (avg.5.04 \pm 0.60 ) was observed at all stations except Veli. From these results, it is quite clear that the shelf waters of the Thiruvananthapuram coast have been exposed to the increased threat of industrial pollution.
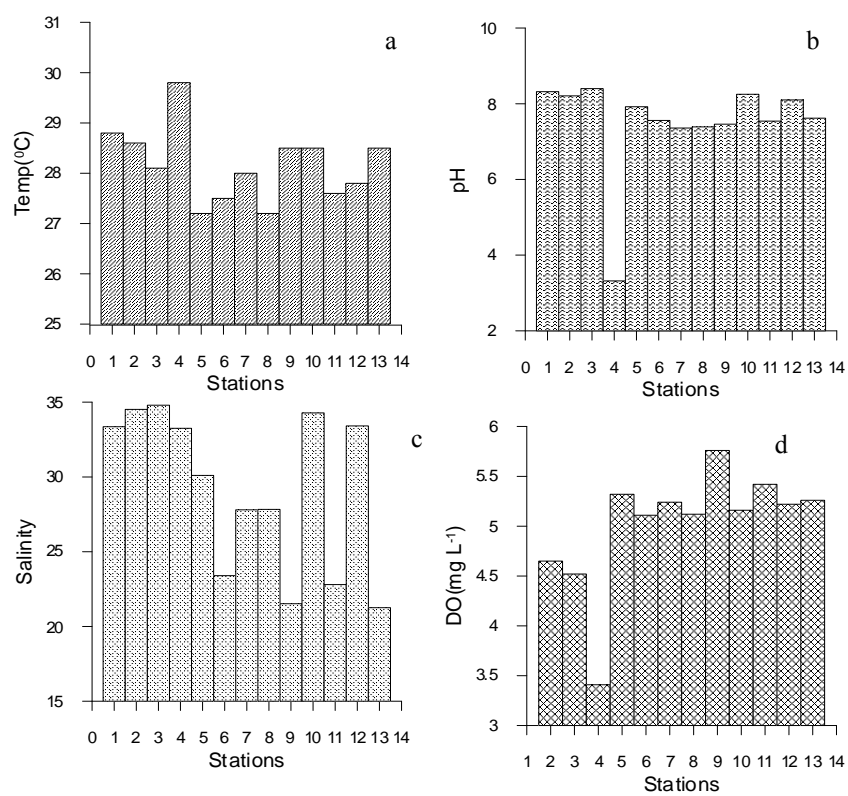

Figure 2. bSpatial variation of hydrographic characteristics along the stations (a) water temperature (b) $\mathrm{pH}$ (c) Salinity(d) Dissolved Oxygen

Concentration of chlorophyll a (Figure 3a) varied from 2.6 - $0.1 \mathrm{mg} \mathrm{m}^{-3}$ with an average of $1.23 \pm 0.94 \mathrm{mg} \mathrm{m}^{-3}$. Highervalues of primary productivity of $0.34 \mathrm{~g} \mathrm{C} \mathrm{m}^{-3} \mathrm{~d}^{-1}$ was at Karwar and lowest of $0.07 \mathrm{~g} \mathrm{C} \mathrm{m}^{-3} \mathrm{~d}^{-1}$ was at Veli with an average of $0.21 \pm 0.09 \mathrm{~g} \mathrm{C} \mathrm{m}^{3} \mathrm{~d}^{-1}$ (Figure $3 \mathrm{~b}$ ). Higher zoo- plankton population density of $859 \mathrm{No} \mathrm{m}^{-3}$ was recorded at Calicut and lowest $\left(64 \mathrm{No} \mathrm{m}^{-3}\right)$ was observed at Veli near shore (Figure 3c). Madhuprathapet al.[41] reported that death of organisms due to effluent could be due to the drastic change in $\mathrm{pH}$ of water, which will create stress on normal metabolism of the overall aquatic life, which was reflected in our study through the pigment concentration and primary productivity at Velitransact (Figure 3a,b).
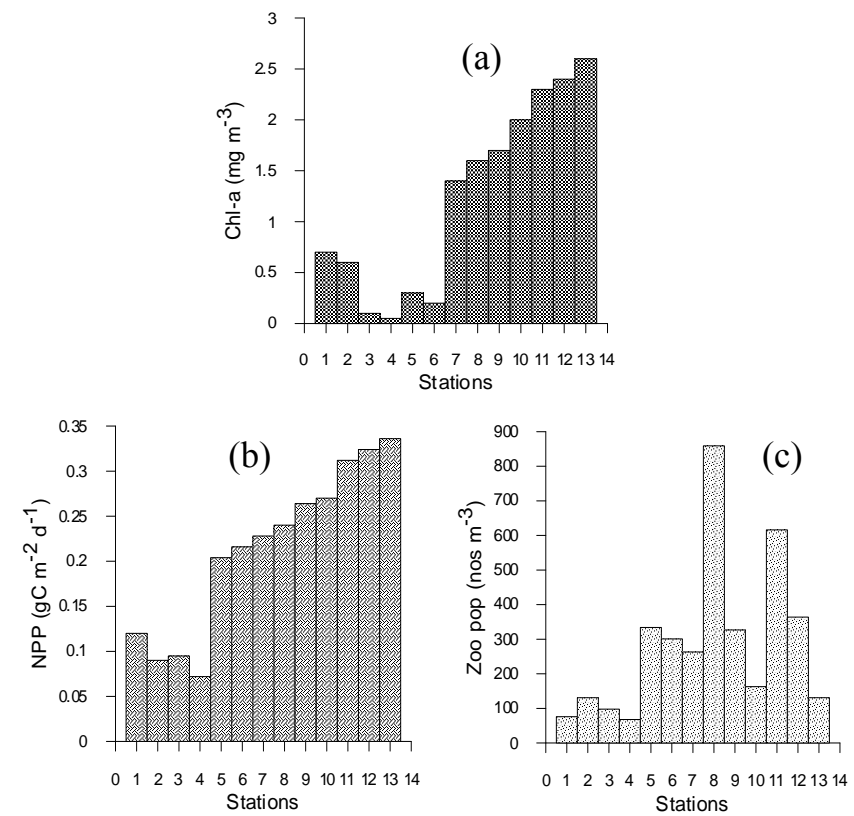

Figure 3. Spatial variation of (a) pigment concentration (b) Primary productivity (c) zooplankton abundance
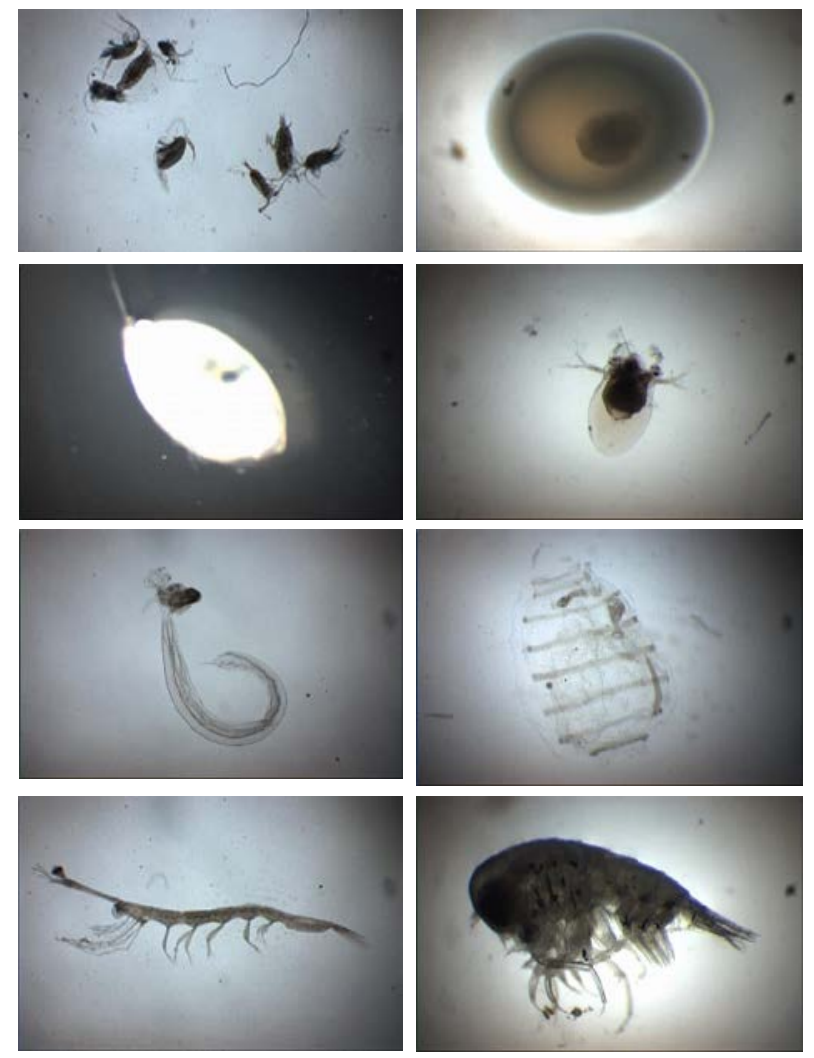

Figure 4. Photomicrographs of some selected zooplankton recorded during the present study 
Copepods, fish eggs, Cladocera, Appendicularians, Decapods,Ostracods, Doliolids and Amphipods were the major zooplankton groups observed along the shelf waters (Figure 4). Overall percentage compositions of zooplankton recorded at different stations are shown in Figure 5. Zooplankton community of thesouthwest coast shared heterogeneous assemblage of many species, covering many taxonomic groups. Population dynamics is related to the physico-chemical factors.

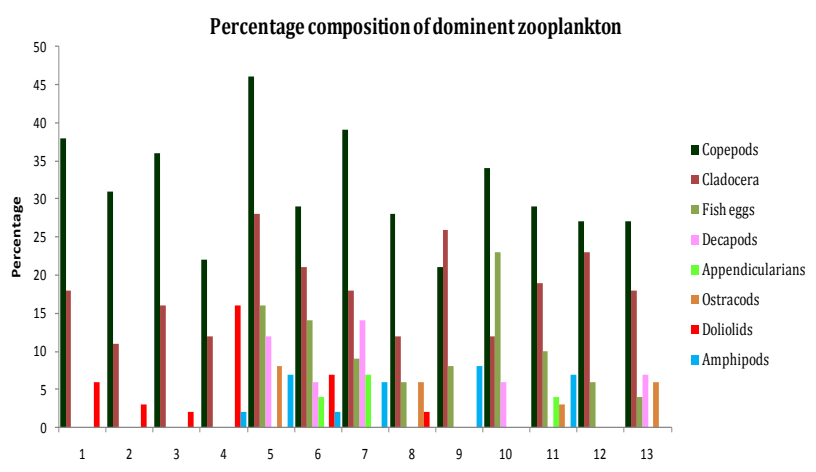

Figure 5. Percentage composition of dominant groups of zooplankton in different stations

The 3D surface plot of zooplankton population against chlorophylla and primary productivity, well demonstrated in Figure 6, indicates that the zooplankton population is not in direct tune with the high chlorophyll concentration and primary productivity. But it could be attributed to salinity variations and marginal stress from the fresh water input. Gross pollution problems at Veli transact owing to the release of untreated effluents from industries and domestic sectors which could be the reason for comparatively low levels of pigment concentration and primary productivity and zooplankton population at Cochin. From the results, it is quite clear that the surface productivity of Veli was drastically decreased especially near the shore, due to higher suspended matter and decreased transparency, apart from the acidic $\mathrm{pH}$ caused for factory effluents, which adversely affect the phytoplankton community, thereby corresponding organic production. This conclusion is in agreement with Bijumonet al.[42]. However, a trend in increased primary productivity positively correlated with pigment concentrationwas observed along the northern transects.

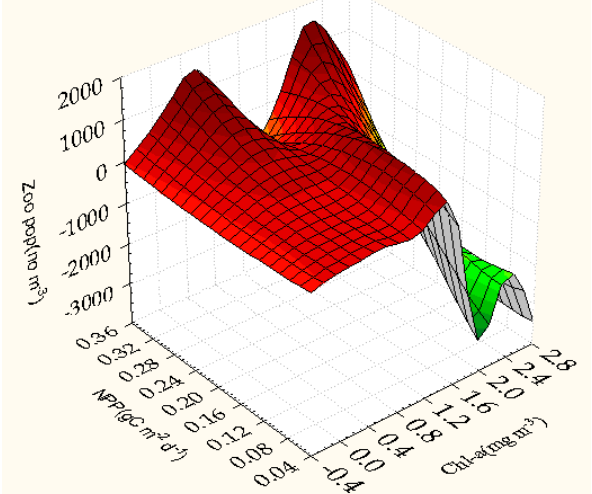

Figure 6. 3D Surface plot of zooplankton population $\left(\right.$ no $\left.\mathrm{m}^{-3}\right)$ against chlorophylla $\left(\mathrm{mg} \mathrm{m}^{-3}\right)$ and NPP $\left(\mathrm{g} \mathrm{C} \mathrm{m}^{-3} \mathrm{~d}^{-1}\right)$ zoo population $\left(\right.$ no $\left.\mathrm{m}^{-3}\right)=$ Distance weighted least squares

Photoprotective compounds traced from the zooplankton from the shelf waters of southwest coast of India are represented in Table 1 and Figure 7. Mycosporine-glycinewas found in zooplankton of all the polluted stations inVeli, Neendakara, and Cochin, probably for the protection from the adverse effect of pollution viz.high discharge of acidic effluents at Veli transact, sewage discharge at Neendakara and dredging activities and sewage disposal at Cochin. Among the photoprtoective compounds, Mycosporine-glycine, exhibit a high antioxidant activity scavenging superoxide anions and inhibiting lipid peroxidation resulting from UV-induced production of ROS besides UVabsorption[43]. This is a self-protective mechanism intimately involved in the prevention of cell damage from the adverse impact.Thus the presence of Mycosporine-glycine in zooplankton of the polluted area is understandable as it protects the organisms from the adverse effects of pollution in addition to photoprotective action by antioxidant metabolites.

Table 1. Photoprotective compounds traced from the zooplankton from the southwest coast of India

\begin{tabular}{ccccccccc}
\hline S1. No. & St.code & Lat. & Long. & MG & PR & PT & SH & UC \\
\hline 1 & Veli-A & $8^{\circ} 29.000$ & $76^{\circ} 49.400$ & - & + & + & - & + \\
2 & Veli-B & $8^{\circ} 30.978$ & $76^{\circ} 52.022$ & + & + & + & - & - \\
3 & Veli-C & $8^{\circ} 30.000$ & $76^{\circ} 49.630$ & - & + & + & - & - \\
4 & TTP & $8^{\circ} 32.566$ & $76^{\circ} 54.014$ & + & + & + & - & - \\
5 & Neendakara & $8^{\circ} 56.183$ & $76^{\circ} 29.795$ & + & + & + & - & - \\
6 & Cochin & $9^{\circ} 56.793$ & $76^{\circ} 11.763$ & + & + & + & - & - \\
7 & Kodungallur & $10^{\circ} 11.546$ & $75^{\circ} 53.365$ & - & + & + & - & - \\
8 & Calicut & $11^{\circ} 13.569$ & $75^{\circ} 44.220$ & - & + & + & - & - \\
9 & Mangalore & $12^{\circ} 57.500$ & $74^{\circ} 47.001$ & - & + & + & - & - \\
10 & Chitrapura & $12^{\circ} 57.500$ & $74^{\circ} 45.200$ & - & + & + & - & - \\
11 & Honovar-A & $14^{\circ} 17.400$ & $74^{\circ} 22.809$ & - & + & + & - & + \\
12 & Honovar-B & $14^{\circ} 17.400$ & $74^{\circ} 22.700$ & - & + & + & - & + \\
13 & Karwar & $14^{\circ} 49.800$ & $75^{\circ} 50.000$ & - & + & + & - & - \\
\hline
\end{tabular}

MG-Mycosporine glycine, PR - Porphyra, PT - Palythine, SH - Shinorine, $\mathrm{UC}$ - Unknown compounds. 


\section{Conclusions}

In the south west coast of India, presence and characterization of the sun screening compounds (MAAs) in the zooplankton community has been reported for the first time. Palythine and porphyra have been detected at all the stations studied. However, at four stations, mycosporine-glycine was present, where high pollution loads were there. Presence of this particular UV-absorbing compound, suggests that it is in response to pollution related environmental stress existing in these areas. High pollution loads in the stations have been reflected through the decreased levels of chlorophylla and of primary productivity. In addition to palythine, porphyra and mycosporine-glycine and some other unknown compounds were also present at Veli andHonavar. Quantification of MAAs of different zooplankton species can be performed to figure out their commercial application.

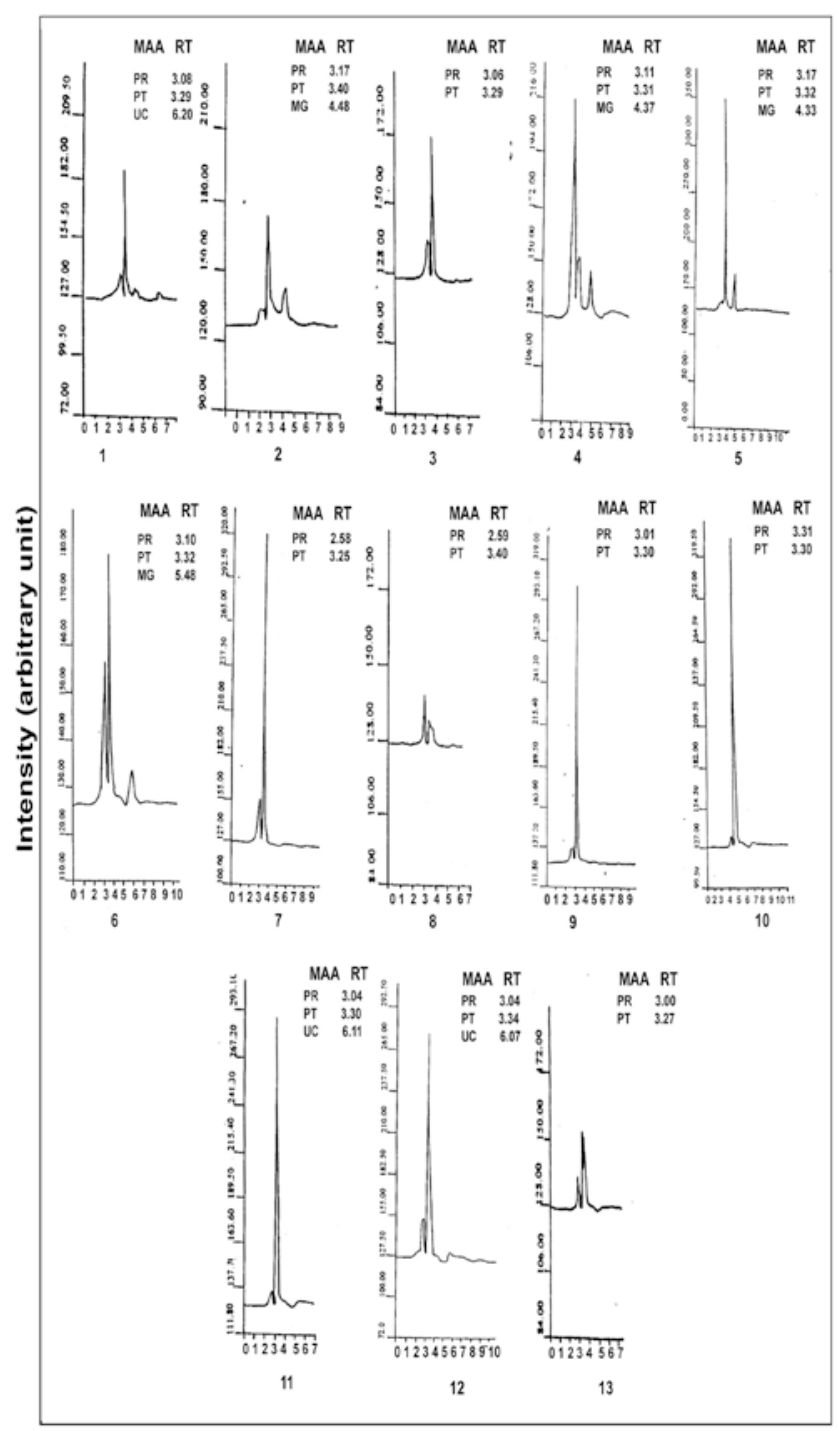

Retension Time

Figure 7. HPLC of mycosporine - like amino acids from zooplankton (stations 1 to 13 ) Reverse-Phase $\mathrm{C}_{18}$ Column; mobile phase $0.2 \%$ acetic acid; flow rate $1.0 \mathrm{ml} \mathrm{min}{ }^{-1}$ chart speed $0.50 \mathrm{~cm} / \mathrm{min}$. Measurements of absorbance at $330 \mathrm{~nm}$

\section{ACKNOWLEDGEMENTS}

Authors are thankful to the Ministry of Earth Sciences, Government of India for financial support during the study period. They also thank the Director, Regional Research Laboratory, Thiruvananthapuram, for encouragement. Deep appreciation to Mrs. M.Sindu, who rendered assistance in some of the experimental work. Thanks are also due to Dr.Oliver Nixdorf, Bremerhaven, Germany, for providing usstandards for the identification of MAAs.

\section{REFERENCES}

[1] Blumthaler, M. andAmbach,W., 1990, Indication of increasing solar ultraviolet-B radiation flux in Alpine regions, Science, 248, 206-208.

[2] Frederick, J.E., Snell, H.E. and Haywood, E.K .,1989,Solar ultraviolet radiation at the earth's surface, Photochem,Photobiol., 50, 443-450.

[3] Cladwell, M.M., 1976,Plant life and ultraviolet radiation, some perspective in the history of the Earth's UV climate,Bioscience, 29, 520-525.

[4] Jeffery, W.H,R.J. Pledger, P. Aas, Hager, S., Coffin, R.B., Haven, R.V., and Mitchell, D.L., 1996,Diel and depth profiles ofDNA photo damage in bacterioplankton exposed to ambient solar ultraviolet radiation,Marine,Ecol.Prog.Ser., 137, 283-291.

[5] Lyons, M.M., Aas, P., Pakulsi, J.D., Waasbergen, L.V ., Miller, R.V., Mitchel D.L. and Jeffery, W.H.,1978, DNA damage induced by ultraviolet radiation in coral- reef microbial communities, Mar.Biol., 130, 537-543.

[6] Karentz, D. Bothwell, M.L., Coffin, R.B., Hanson, A., Herndl, G.F., Kilham, S.S., Lesser, M.P., M.0. Lind Ell, RE. Moeller, Morris, D.P.,Neale, P.J., Sanders, R.W ., Weilerl, C.S and Wetzel, R.G., 1994, Impact of UV-B radiation on pelagic freshwater ecosystems, Report of working group on bacteria and phytoplankton,Arc.Hydrobiol.BeihErgenbn.Lomnol., 43, 31-69.

[7] Leach, C.M., 1965, Ultraviolet-absorbing substances associated with light-induced sporulation in fungi, Canadian, J. Botany., 43,185-200.

[8] Favre-Bonvin, Arpin, J. N., and Brevard, C., 1976, Structure de la mycosporine, Can.J.Chem.,54, 1105-1113.

[9] Brook, B.J., 1981,Protective function of an ultraviolet absorbing compound associated with conidia of Glomerella cingulated, J. Botany, 19, 299-304.

[10] Yong, H. and Patterson, V.J., 1995,Small-molecule antioxidants in marine organisms; antioxidant activity of mysocporine glycine,Comp.Biochem.Physiol.,112, 105-114.

[11] Karentz, D. McEuen, F.S., Land, M.C andDunlap,W.C., 1991,Survey of mycosporine-like amino acid compounds in Antarctica marine organisms, potential protection from ultraviolet exposure,Mar.Biol., 108, 157-166.

[12] Dunlap, W.C. and Yamamoto,Y.,1995, Small-molecule an- 
tioxidants in marine organisms; antioxidant activity of mycosporine glycine,Comp.Biochem.Physiol.,112B, 105-114.

[13] Favre-Bonvin, Bernillon, J. J., Salain, N., and Arpin, N. 1987, Biosynthesis of mycosporines,mycosporineglutaminol in Trichotheciumroseum,Phytochemistry, 26, 2509-2514.

[14] Sommaruga, R., Whitehead, K., Shick, J.M., Lobban, C.S., 2006, Mycosporine-like amino acids in the zooxanthella-ciliate symbiosis Maristentordinoferus, Protist., $157,185-191$

[15] Kinzie, R.A.III. Banaszak, A.T. and Lesser,M.P., 1998, Effects of ultraviolet radiation on primary productivity in a high altitude tropical lake,Hydrobiologia.,385,23-32.

[16] Villafane, V.E.M., Andrade, V., Lairana, F., ZarattiandHelbling, E.W.,1999, Inhibition of phytoplankton photosynthesis by solar ultraviolet radiation, Studies in Lake Titicaca,Bolia. Freshwat,Biol,42,215-224.

[17] Hessen, D.O. and Sorensen, F.S., 1990,Photprotective pigmentation in Alpine zooplankton population, Aqua fenn.,20, 165-170.

[18] Loffler, H. 1969, High altitude lakes in Mount Everest region. -Verh.Int.Verein. Limol.,17, 373-385.

[19] Tartrotti, B., Cabrera, S., Senner ,P andSommaruga, R., 1991, Survivorship of Cyclops abbssorumtatricus (Cyclopoida-copepoda) and Boeckellagracilipes (Calanoida, Copepoda) under ambient levels of solar UV radiation in tow high mountain lakes,J.Plankton Res., 21, 540-560.

[20] Byron, E.R.,1982,The adaptive significance of colanoid copepod pigmentation, A comparative and experimental analysis, Ecology, 63,1871-1886.

[21] Lauriat, I., Lamia, A andSommaruga, R.,2002, Distribution of mycosporine-like amino acids and photoprotectiove carotenoids among freshwater phytoplasam assemblages,Aquat.Micob.Ecol.,26, 283-294.

[22] Hansson, L.A., Hylander, S.,2009, Effects of ultraviolet radiationon pigmentation, photoenzymatic repair, behavior, and communityecology of zooplankton,Photochem. Photobiol.Sci., 8,1266-1275.

[23] Bjerke, J.W., Lerfall, K, Elvebakk, A.,2002. Effects of ultravioletradiation and PAR on the content of usnic and divaricaticacidsin two arctic-alpine lichens,PhotochemPhotobiol Sci., 1,678-685.

[24] Cockell, C.S., Knowland, J.,1999, Ultraviolet radiation screeningcompounds,Biol Rev., 74,311-345.

[25] Gauslaa, Y., McEvoy, M., 2005, Seasonal changes in solar radiation drive acclimation of the sun-screening compound parietinin the lichen Xanthoriaparietina, Basic Appl. Ecol., $6,75-82$.

[26] Klisch, M., Ha“der, D.P., 2008,Mycosporine-like amino acids andmarine toxins - the common and the different, Mar. Drugs., 6,147-163.

[27] Singh, SP, Kumari, S., Rastogi, R.P., Singh, K.L., Sinha, R.P., 2008,Mycosporine-like amino acids (MAAs), chemical structure,biosynthesis and significance as

UV-absorbing/screening compounds, Ind. J. Exp. Biol., $46,7-17$
[28] Sinha, R.P., Singh, S.P., Ha"der, D.P., 2007, Database on mycosporinesandmycosporine-like amino acids (MAAs) in fungi,cyanobacteria, macroalgae, phytoplankton and animals, J.Photochem.Photobiol. B Biol., 89,29-35.

[29] Sommaruga, R., Whitehead, K., Shick, J.M., Lobban, C.S., 2006, Mycosporine-like amino acids in the zooxanthella-ciliate symbiosis Maristentordinoferus, Protist., 157,185-191.

[30] Helbling, E.W., Menchi, C.F., Villafañe,V.E.,2002,Bioaccu mulationand role of UV-absorbing compounds in two marine crustaceanspecies from Patagonia, Argentina, PhotochemPhotobiolSci 1,820-825Strickland, J.D.H., Parsons, T.R., 1972, A Practical Handbook of Sea Water Analysis, second ed., vol. 167, Fisheries Research Board, Canada, p.310.

[31] Banse, K., 1959, On upwelling and bottom-trawling off the southwest coast of India, Journal of Marine Biological Association of India, 1, 33-49.

[32] Lathipha, P. N., Murthy, A. V. S., 1985, Studies of Upwelling along the west coast of India using geo potential Anomaly. Indian Journal of Marine Science, 14, 10-14.

[33] Grasshoff, K., Ehrhardt, M., Kremling, K., 1999,Methods of Sea water analysis, $3^{\text {rd }}$ edition, VerlagChemie, Weinheim, Germany.

[34] Strickland, J.D.H., Parsons, T.R., 1972, A Practical Handbook of Sea Water Analysis, second ed., vol. 167. Fisheries Research Board, Canada, p.310.

[35] Parsons, T.R., Maita, Y., Lalli, C.M., 1984,A manual of chemical and biological methods for sea water analysis, Pergamon Press, New York, pp. 101-103.

[36] Goswami, S.C. and Padmavathi, G.,1996, Zooplankton production, composition and diversity in the coastal waters of Goa, Indian J. Mar. Sci., 25,91-97.

[37] Wilson, C.B., 1932,Thecopepoda of the woodshols region, Massachusetts. Smithonian Institute, U.S. Natl. Mus. Bull., $158,1-635$

[38] Kasthurirangan, L.R., 1963, Key to identification of the Common pelagic copepods of indian coastal waters, CSLS publication, 128pp.

[39] Dunlap, W.C. and Chalker, B.E.,1986, Identification and Quantitation of near, UV- absorbing compounds (S-320) in a hermatypicseleractinian, Coral Reef., 5, 155-159.

[40] Robin, R.S., Muduli, P.R., Vishnu VardhanK., Rajkumar J.S.I., Prasun,G. and Balasubramanian,T., 2010, Nutrients and its influence on biological productivity along Kerala coast, India, International Journal of Current Research, 10,038-045.

[41] Madhupratap, M.,1979, Distribution, community structure and species succession of copepods from Cochin backwaters, Indian J. Mar.Sci.,8, 1-8.

[42] Bijumon, K. B., R. S Robin, S. Sunil Kumar and P.P. Ouseph, 2000, Effect of factory effluent on the Biological productivity of coastal marine system at veli, Thiruvananthapuram. Proc. of the tenth Kerala, Sci., Cong., 205-207.

[43] Dunlap, W.C. and Yamamoto,Y.,1995, Small-molecule antioxidants in marine organisms; antioxidant activity of mycosporine glycine.Comp.Biochem.Physiol.,112B, 105-114. 